\section{Effects of hypophyseal or thymic allograft on thymus development in partially decerebrated chicken embryos: expression of PCNA and CD3 markers}

\author{
M. Aita, ${ }^{1}$ F. Benedetti, ${ }^{1}$ E. Carafelli, \\ E. Caccia, ${ }^{2}$ N. Romano ${ }^{2}$
}

'Department of Physiology and Pharmacology "V. Erspamer", Faculty of Medicine, University "La Sapienza”, Rome, Italy

2Department of Environmental Science, University of Tuscia, Viterbo, Italy

\begin{abstract}
Changes in chicken embryo thymus after partial decerebration (including the hypophysis) and after hypophyseal or thymic allograft were investigated. Chicken embryos were partially decerebrated at $36-40 \mathrm{~h}$ of incubation and on day 12 received a hypophysis or a thymus allograft from 18-day-old donor embryos. The thymuses of normal, sham-operated and partially decerebrate embryos were collected on day 12 and 18. The thymuses of the grafted embryos were collected on day 18 . The samples were examined with histological method and tested for the anti-PCNA and anti-CD3 immune-reactions. After partial decerebration, the thymic cortical and medullary compartments diminished markedly in size. Anti-PCNA and anti-CD3 revealed a reduced immunereaction, verified also by statistical analysis. In hypophyseal or grafted embryos, the thymic morphological compartments improved, the anti-PCNA and anti-CD3 immune-reactions recovered much better after the thymic graft, probably due to the thymic growth factors and also by an emigration of thymocytes from the same grafted thymus.
\end{abstract}

\section{Introduction}

The primary lymphatic organs in birds, thymus and bursa of Fabricius, play a central role in differentiating lymphocytes responsible for specific immunological responses, such as cellular (T lymphocytes, in thymus) $)^{1,2}$ and humoral (B lymphocytes, in bursa). ${ }^{3}$ In thymus, the various reticular-epithelial cells, the epithelial cysts and humoral factors stabilise the correct milieu involved in processing the T-cell precursors and inducing them to become mature and differen- tiated thymocytes or T-cells. ${ }^{4-6}$ Chicken embryonal thymus is organized in cortex and medulla. In the cortex, lymphocytes overspread the reticular-epithelial cells, and in the medulla, at the centre of the lobe, isolated or clustered epithelial cells ${ }^{7,8}$ and cysts, of the intra- or inter-cellular type ${ }^{8-11}$ are well visible, whereas macrophages, myoid cells and Hassall's corpuscles are rare. Lymphocytes are less numerous than in the cortex.

The thymus, besides to have an immune function, has also an endocrine function; in fact endocrine-like cells were described in embryonal chicken thymus. ${ }^{9-12}$ The thymus takes part in the mechanisms of reciprocal effects between the immune and the neuroendocrine interactions in mammals and in birds. ${ }^{13-18}$ It has been characterized the influence of the hypothalamic-pituitary-gonadal axis and that of thyroid hormone on the immune system, in mammals ${ }^{19-21}$ and in birds..$^{22}$

The production of several hormones has been described in the thymus of mammals and birds, as steroids, ${ }^{23}$ glucocorticoids, ${ }^{24-26}$ growth hormone, ${ }^{27}$ POMC-derived peptides, ${ }^{28-30}$ and neuropeptides. ${ }^{31,32}$

In accordance with the reciprocity of the actions between immune and neuro endocrine system, several thymic factors were found to be active on nervous and endocrine system, (reviewed in 33) and localized in mammalian thymus. ${ }^{33-35}$ In birds, a specific hormonal factor, the avian thymic hormone (ATH), a parvalbumin, has been extracted and localized only in cortical reticular-epithelial cells. ${ }^{36-38}$ The thymic factor thymostimulin was extracted from calf thymus ${ }^{39}$ and detected, using an antithymostimulin antibody, in mammals ${ }^{40,41}$ and humans. ${ }^{42}$ In avian embryonal, post hatching and aging thymuses ${ }^{43-46}$ the thymostimulin-like immune reactivity was observed in vacuolar and cystic epithelial cells, around an epithelial cluster or arranged in small groups of epithelial cells. The importance of the lack of hypophysis for the endocrine glands development in the chicken embryo was described by Fugo $0{ }^{47}$ without noting any histological changes in thymic structure. The effects of embryonic pars distalis grafts on different endocrine glands after a chick embryos hypophysectomy was evidenced by Betz. ${ }^{48}$

On the contrary, in our experience, early partial decerebration including the ablation of hypophyseal anlage, caused thymus underdevelopment with a reduction in the number and differentiation of reticular-epithelial cells as compared with normal embryos. ${ }^{49-51}$ Romano et $a l .{ }^{8}$ in an ultrastructural study, found evident variations in the cortical zone and in the small medullary zone; there were few clusters and few cysts of the intracellular type with some modifications compared with normal thymus. Aita and Romano ${ }^{46}$ noted also the lack of the
Correspondence: Mariangela Aita, Department of Physiology and Pharmacology "Vittorio Erspamer", Faculty of Medicine University La Sapienza, P.le A. Moro 5, 00185 Roma, Italy.

Tel. +39.06.49910734.

E-mail: mariangela.aita@uniromal.it

Key words: hypophysectomy, hypophyseal and thymic allograft, chicken embryonal thymus, PCNA, CD3 markers.

Received for publication: 3 February 2010. Accepted for publication: 12 July 2010.

This work is licensed under a Creative Commons Attribution 3.0 License (by-nc 3.0)

(C) Copyright M. Aita et al., 2010

Licensee PAGEPress, Italy

European Journal of Histochemistry 2010; 54:e37 doi:10.4081/ejh.2010.e37

synthesis of the thymic factor "thymostimulin" and the reduction of some enzymatic pathways as ATP ase and SDH. Regarding the differentiation of T-cell subsets, Moreno et al., ${ }^{52}$ making a partial decapitation at 33-38 hours of incubation, found that T-cell subsets were affected with a decline of $\mathrm{CD}^{+}$and $\mathrm{CD} 8^{+}$cells and TCR $\alpha \beta$-expressing cells. A hypophyseal graft in partially decerebrate chick embryo determined an increase of total thymus size and of medullary epithelial cells ${ }^{53}$ with a considerable recovery of the cytology, even if a normal morphology is not completely accomplished ${ }^{8}$ and with the recovery of the synthesis of thymostimulin and of the enzymatic pathways. ${ }^{46}$ The aim of this research is: i) to verify if an allograft of thymus in partially decerebrate embryos may improve the morphological variations described in partially decerebrate embryos $^{8,17,21}$ and compare these results with the normal thymus, ii) to ascertain if a partial decerebration, followed by a hypophyseal or thymic allograft may influence the expression of the nuclear PCNA/cyclin marker or the expression of the membrane CD3 marker in thymocytes and to compare these results with the normal thymus and examine thoroughly previous research conducted in our laboratory. ${ }^{54,55}$ The cyclin, an acidic polypeptide of MW $36 \mathrm{kDa}$, is present in several cells nucleus. Its synthesis is followed by DNA synthesis and its level increase in $\mathrm{S}$ phase of the cell cycle ${ }^{56-60}$ PCNA (the proliferating cell nuclear antigen) was demonstrated to be identical with cyclin. ${ }^{61}$ Thereafter, an auxiliary protein specific for DNA polymerase $\delta$, was extracted from foetal or adult calf thymus. ${ }^{62,63}$ Bravo et al. ${ }^{64}$ reported that cyclin/PCNA is the auxiliary protein of DNA polymerase $\delta$. The marker CD3 is expressed in the cortical and medullary zones of the thymus during the ontogenic period, by 
T lymphocytes, during their differentiation until becoming mature thymocytes. ${ }^{1,5,55,65-70}$

\section{Materials and Methods}

\section{Experiments}

White Leghorn chicken embryos (Gallus gallus domesticus) were used for three series of experiments: i) the prosencephalon, part of mesencephalon including the hypophyseal anlage and the presumptive anlage of the Rathke pouch were removed from 36-40 h embryos (PD) using Fugo's technique; 47 ii) some PD embryos, at d 12 of incubation, received a hypophyseal allograft onto the chorio-allantoic membrane from an 18 day-old donor embryo, (PD+H); iii) some PD embryos, at $\mathrm{d} 12$ of incubation, received a thymic allograft onto the chorio-allantoic membrane from an 18 day-old donor embryo (PD+Th).

The experimental thymuses were compared with normal and sham-operated embryos. For the sham-operation a small window was opened in the embryonic shell, at $36 \mathrm{~h}$ and covered with a sterilized tape at $40 \mathrm{~h}$. $0 \mathrm{n} \mathrm{d} 12$, the sham-operated embryos were opened for the second time and then covered and sealed again. Thymuses of normal, sham operated and PD embryos were collected at the $\mathrm{d} 12$ and 18 of incubation. Every experimental chick was examined to ascertain hypophyseal removal. Thymuses of $\mathrm{PD}+\mathrm{H}, \mathrm{PD}+\mathrm{Th}$ embryos were collected at $\mathrm{d} 18$. In $\mathrm{PD}+\mathrm{H}$ the grafted hypophysis as well as in $\mathrm{PD}+\mathrm{Th}$, the grafted thymus were histologically examined. The embryos' stage was evaluated by the days of incubation and by Lillie's tables of development. ${ }^{71}$ We repeated experiments for 4 times. We utilized 50 eggs for normal and sham operated embryos, removed at $\mathrm{d} 12$ and 18 , in total $\mathrm{n}=36$ surviving embryos. For the experiments, a total amount of 1200 eggs was used. After the partial decerebration at $36-40 \mathrm{~h}$, the mortality was high. The surviving embryos at $\mathrm{d} 12$ were 96. Ten of them were removed as (PD) embryos. From the remaining 86,30 embryos were used for grafts, 15 grafted with hypophysis, surviving at day $18 \mathrm{n}=10(\mathrm{PD}+\mathrm{H})$ embryos, 15 grafted with thymus, surviving at day 18, n=9 (PD+Th) embryos; among them, 5 embryos had the thymic graft with a remnant of histological structure. The remaining 56 PD embryos were left till d 18, surviving 9 embryos.

\section{Thymic specimens}

Two thymic lobes from right side and two from left side of the neck from normal, shamoperated, PD, PD+H and PD+Th, were fixed in Bouin's liquid for $8 \mathrm{~h}$ at room temperature, dehydrated and embedded in paraffin wax. Transversal serial sections, from a whole thymic lobe, of $5 \mu \mathrm{m}$ thick were stained by haematoxylin-eosin for histological examination. Other sections were processed with immune-histological methods (anti PCNA/ cyclin and anti-CD3, antibodies).

\section{Anti-PCNA/cyclin immune reaction}

The method used for the anti-PCNA/cyclin antibody reaction has been reported in detail in previous studies. ${ }^{72,73}$ In brief, the thymic sections were incubated with the primary antibody (anti-PCNA, PC 10 mouse monoclonal antibody (moAb) IgG Sigma, n. P-8825) at the dilution of 1:1000 in 1\% normal horse serum in phosphate buffer, $\mathrm{pH} 7.2$, overnight at $4^{\circ} \mathrm{C}$. The immune reaction was revealed by $0.05 \% 3-3$ ' diaminobenzidine (DAB) tetrahydrochloride with $1 \%$ nickel-sulfate and $0.01 \%$ hydrogen peroxide in $0.05 \% \mathrm{M}$ Tris-HCl buffer (SigmaAldrich). No counterstain was used. Slides were then dehydrated and coverslipped using Entellan (Merck, Germany). The specificity of the immune staining was tested by replacing the primary antiserum with immune horse serum alone.

\section{Anti-CD3 immune reaction}

Thymic sections were treated with a PAP method using an anti-CD3 antibody (a pan-T marker, clone UCHT1 by DAK0). The immune reaction was revealed by 3 -amino-9-ethyl-carbazole (AEC-immune staining DAKO PAP kit). No sections were counterstained. Slides were then dehydrated and coverslipped with Tissue Adhesive PC-380 k (Ortho). A non-immune serum (DAK0) was used as a negative control.

\section{Statistical analysis}

In each specimen, multiple sets of consecutive sections were differentially immunestained with the anti-PCNA and anti-CD3 antibodies. Counts of immune reactive cells (nucleated only, cell area ranging from 4 to 100 $\mathrm{mm}^{2}$ ) in $1 \mathrm{~mm}^{2}$ area of thymuses were performed with a computer-assisted image analysis system (Axoscope-KS300-Zeiss) by an external observer, unaware of treatments. The number of immune reactive cells was then calculated by averaging the cell numbers from 4 specimens per treatment, and expressed as the mean \pm standard deviation (SD). Numerical results were analysed by means of analysis of two-tail-T student test.

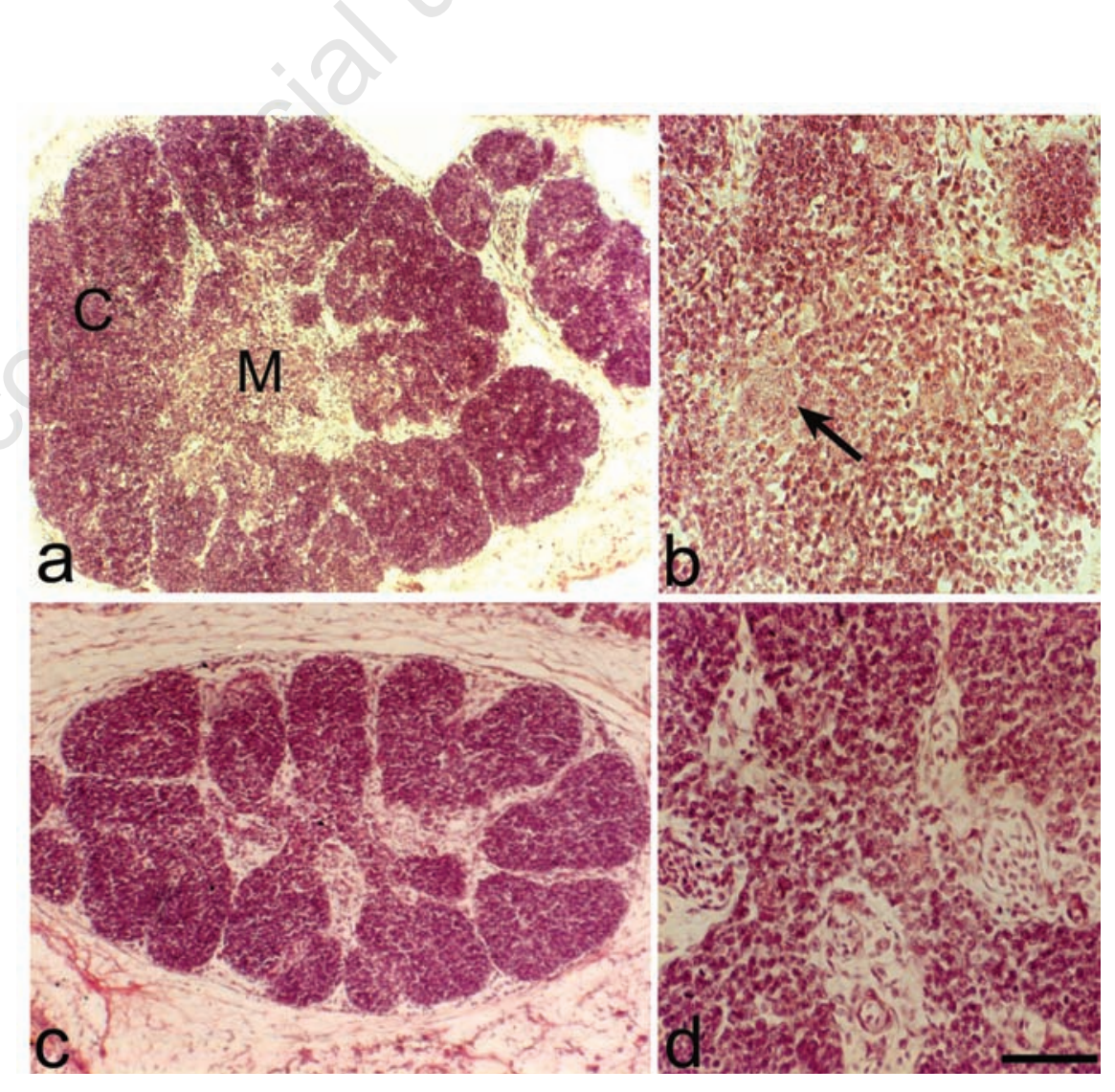

Figure 1. Haematoxylin-Eosin. Thymuses from 12 day-old embryos. (a) Normal thymus. Note the division in cortex $(C)$ and medulla $(M)$. (b) Normal thymus. Small epithelial clusters with few cells (arrow), in the medulla. (c) PD thymus. Note the reduction of the thymic size. (d) PD thymus, in the medulla no epithelial cells are present. Scale bar: a,c: $200 \mu \mathrm{m}$; b: $40 \mu \mathrm{m}$; d: $16 \mu \mathrm{m}$. 


\section{Results}

Since no morphological or immune-histochemical differences were found between thymuses from normal and sham-operated embryos, we henceforward refer to both groups as normal embryos.

\section{Histological findings}

In normal embryos of $12 \mathrm{~d}$, the thymus was set up by a cortex divided in lobes and a central medulla with small epithelial clusters made up of few cells (Figure 1a, b). In PD embryos of 12 $\mathrm{d}$, the thymus was underdeveloped and the cortical lobes width was reduced. At the centre of the organ the medulla was very small, no epithelial cells were present (Figure 1c, d).

In normal embryos, the thymus of $18 \mathrm{~d}$ (Figure $2 \mathrm{a}, \mathrm{b}$ ) revealed a capsular line of connective tissue, which gives rise to the septa dividing the cortex in lobes rich in thymocytes, veiling the presence of the reticular-epithelial cells. The medulla, mainly at the centre of the thymus, presented a less number of thymocytes, making so more distinct the epithelial cells; few of them were isolated, whereas the majority was assembled forming large clusters, where light and dark cells were visible, or epithelial cells with inside vacuoles, or cysts of the intra or intercellular type. Hassall's corpuscles and myoïd cells were rare.

In PD embryos of $18 \mathrm{~d}$ the thymus was always underdeveloped, no epithelial cluster was present in the medulla (Figure 2c, d).

In every grafted embryos, either with hypophysis or with thymus, no host immune reaction was detected.

In $\mathrm{PD}+\mathrm{H}$ embryos, the cortex was enriched in thymocytes. The medulla showed an improvement of epithelial clusters, without anyway reaching the number of the normal thymus (Figure 2e, f).

The histological control of the grafted hypophysis stained with haematoxilin-eosin showed a well-preserved organization as cellular cord. The graft contained mainly adenohypophyseal tissue, with scarce neuro-hypophyseal fibres (data not shown).

In PD+Th experiments we examined the respective thymic grafts. Two types of residual grafts were observed: i) a thymic fragment with a remnant of the histological structure (Figure 3a); ii) a thymic fragment without the typical histological structure, but only with few thymocytes, connective and adipose tissue (Figure 3b).

In PD+Th thymus, collected from the embryo where the graft still had a histological structure, we found a good recovery of the thymic size, even if the cortical lobes were not well separated, the medulla at the centre was
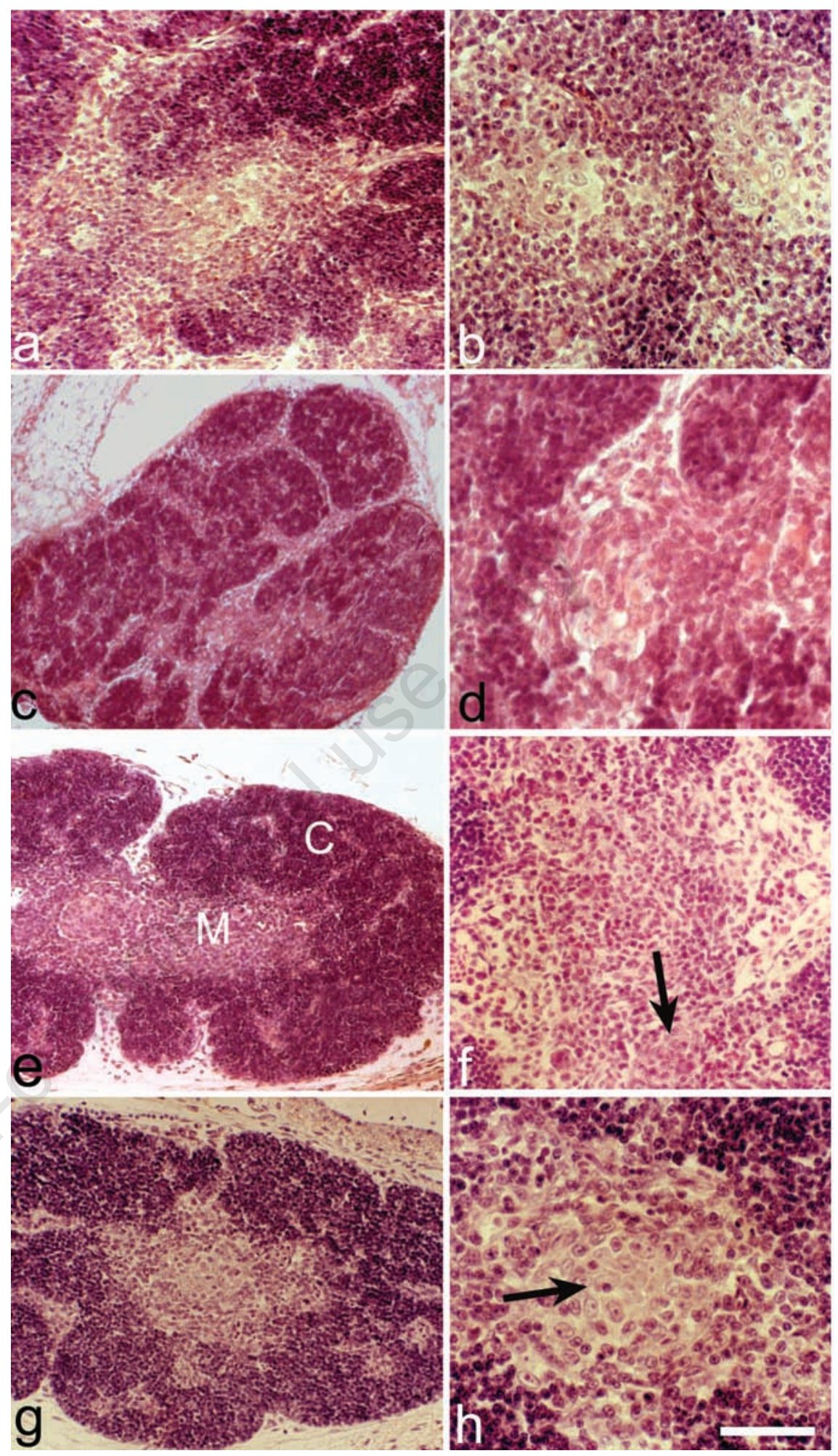

Figure 2. Haematoxylin and eosin. Thymuses from 18 day-old embryos. (a) Normal thymus. (b) The medullary clusters are made up of epithelial cells, some have cystic appearance of the intra-or intercellular type. (c) PD thymus. The size is clearly reduced. (d) PD thymus. In the medulla no clusters of epithelial cells are present. (e) $\mathrm{PD}+\mathrm{H}$ thymus. The cortex (C) is similar to that of normal thymus and there is an improvement of the medullary zone (M). (f) In the medulla the epithelial clusters are present (arrow) without reaching the number of the normal thymus. (g) PD+Th thymus. Note the good recovery of the total size. (h) PD+Th thymus. Good improvement of the epithelial cluster in the medulla (arrow). Scale bar: a,c,e,g: $100 \mu \mathrm{m}$; b,d,h: $40 \mu \mathrm{m}$; f: $25 \mu \mathrm{m}$. 
large and the improved clusters were formed by few cells not reaching the form and the number of the normal thymus (Figure $2 \mathrm{~g}, \mathrm{~h}$ ).

In PD+Th thymus, collected from the embryo where the graft was without the histological structure, the thymic size was increased in a considerable way, the medulla was large and located not only in the centre, but also inside the cortical lobes, the epithelial clusters are improved without anyway reaching the form and the number of the normal thymus (data not shown).

\section{Anti-PCNA immune reaction}

In normal thymus, an intense immune-reaction was located in the nuclei of cortical thymocytes, indicating an efficient proliferation activity. The medullary thymocytes were not immune-reactive (Figure 4a).

In PD thymus, the nuclei of few thymocytes of the external cortical zone were immunereactive; the nuclei of the other thymocytes were weakly immune-stained. In the medulla no thymocyte was reactive (Figure $4 \mathrm{~b}$ ).

In $\mathrm{PD}+\mathrm{H}$ thymus, there was a recovery of the total size of the cortex and the nuclei of many thymocytes, spread in the total cortex, were positive. No thymocyte was reactive in the medulla (Figure 4c).

In PD+Th thymus, there was a notable recovery of the number of the total cortical thymocytes, more evident in the situation of the graft without the histological structure. The nuclei of thymocytes were positive to this immune reaction. No positive thymocyte in the medulla (Figure 4d).

Image analyses and calculation of PCNA positive thymocytes reported in Figure 5 revealed that there was a significant decrement in $\mathrm{PD}$ and $\mathrm{PD}+\mathrm{H}(\mathrm{P}<0.05)$ compared with normal thymus and a significant increment in the group of $\mathrm{PD}+\mathrm{Th}$ compared with the other groups $(\mathrm{P}<0.001)$.

\section{Anti-CD3 immune reaction}

In normal thymus, the cortical thymocytes revealed a strong membrane immune-staining, making up the characteristic ring. The medullary thymocytes were also immune-reactive (Figure 6a). In PD thymus, there was a reduction of the number of the reactive thymocytes. Few medullary thymocytes revealed the membrane immune-reactivity (Figure 6b). In $\mathrm{PD}+\mathrm{H}$ thymus, there was a recovery of the total number of reactive thymocytes. Also in the medulla, the thymocytes were reactive (Figure 6c). In PD+Th thymus, also in both experimental samples, there was a good recovery of the number of the immune-reactive thymocytes as in the cortex and as in the medulla (Figure 6d). Image analyses and calculation of CD3 positive thymocytes reported in Figure 7 revealed that in

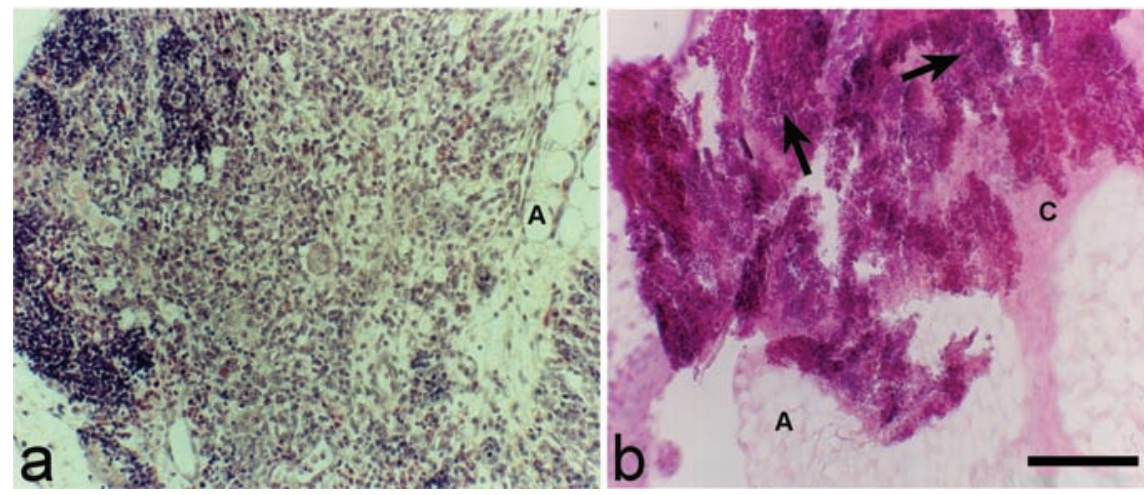

Figure 3. Two types of thymic residual grafts. (a) It is possible to note some remnant of the histological structure. (b) Note the presence of some thymocytes (arrows), connective (C) and adipose (A) tissue. Scale bar: a: $80 \mu \mathrm{m}$; b: $120 \mu \mathrm{m}$.
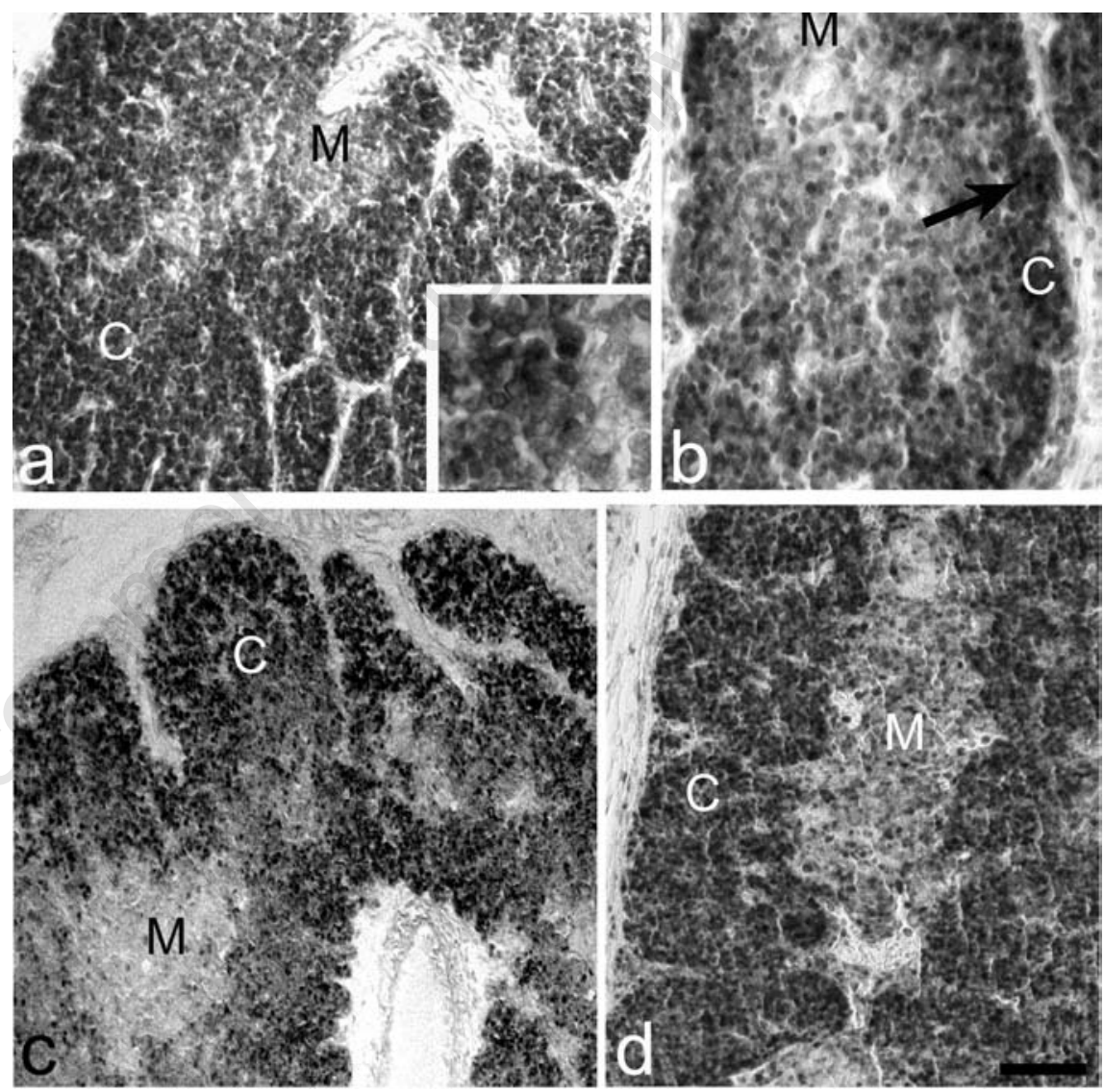

Figure 4. Anti-PCNA reaction. (a) Intense immune reaction in the normal cortical (C) thymocytes, $M=$ Medulla. Inset: magnification of the cortical positive thymocytes. (b) PD thymus. In cortex, $(C)$ few thymocytes of the external zone are strongly positive, the other thymocytes are weakly stained, $M=$ Medulla. (c) PD+H thymus. Good immune reaction in the total cortical (C) thymocytes, $M=$ Medulla. (d) PD+Th thymus. Considerable recovery of the immune staining in the total cortical (C) thymocytes, M=Medulla. Scale bar: a,d: $37 \mu \mathrm{m}$; b: $220 \mu \mathrm{m}$; c: $250 \mu \mathrm{m}$.

$\mathrm{PD}$ and in $\mathrm{PD}+\mathrm{H}$ there was no significant difference in cellular density compared with normal thymus. On the contrary, in the PD+Th there was a significant increment $(\mathrm{P}<0.001)$ of the number of CD3 positive cells respect to other experimental groups, together with an enhancement of the number of thymocytes. In the medulla the groups of $\mathrm{PD}+\mathrm{H}$ and $\mathrm{PD}+\mathrm{Th}$ revealed both a significant increment $(\mathrm{P}<0.001)$ of positive cells as compared with normal and PD groups. 


\section{Discussion}

This research provides new information on the morpho-functional changes in the thymuses taken from partial decerebrate (including hypophysis) chicken embryos and from embryos grafted with a hypophysis or a thymus. At the best of our knowledge, this is the first time that a thymic graft was made on hypophysectomized chicken embryos. As well as confirming previous histological observations for the hypophysectomized chicken embryos and for the embryos grafted with a hypophysis ${ }^{8,46,50,53}$ this study provides new data, showing that also the graft of a thymus on the hypophysectomized embryos brings to an improvement of the size of cortex, medulla and of the epithelial clusters. Anyway, both grafts do not recover completely the morphological structure, probably because after the hypophysectomy, the thymus is seriously reduced and damaged already at $\mathrm{d} 12$ and so the functional contribution of grafts do not allow the complete thymic maturation and differentiation in 6 days.

Concerning PCNA immune-reaction, few papers deal with thymocytes and thymus, in contrast with the immune localization in different tissues. ${ }^{74}$ This study confirms the data on the PCNA immune-reactivity in normal embryonic thymus, previously described. ${ }^{55,75}$

The strong PCNA thymocytes labelling we detected throughout the control cortex is in contrast with the hypophysectomized thymus, where the strong PCNA labelling was present only in the external cortex, whereas in the other thymocytes of the remaining cortex the PCNA reaction was faint, as confirmed by

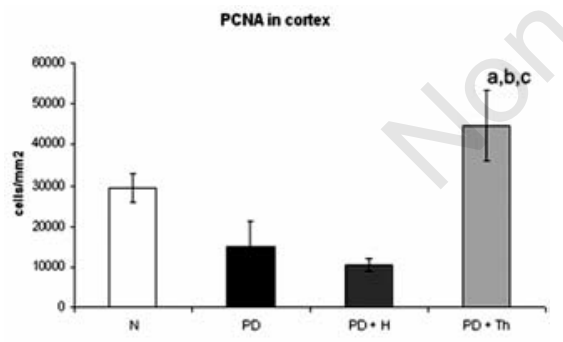

Figure 5. Anti-PCNA-Density (number of cells $/ \mathrm{mm}^{2}$ ) of PCNA ${ }^{+}$thymocytes (detected by immune histochemistry) in thymus of normal $(\mathrm{N})$, partially decerebrated (PD), partially decerebrated + hypophyseal graft $(\mathrm{PD}+\mathrm{H})$ and partially decerebrated + thymus graft (PD+Th). Data refer to quantitative analysis on tissue section and are expressed as mean \pm SD. The two-tail Student t-test for unpaired data shows a significantly increase number of positive cells in cortex (a: $\mathrm{PD}+\mathrm{Th}$ vs. $\mathrm{N}, \mathrm{P}<\mathbf{0 . 0 0 1}$; b: $P D+T h$ vs. $P D, P<0.001$; c: $P D+T h$ vs. $\mathrm{PD}+\mathrm{H}, \mathrm{P}<\mathbf{0 . 0 0 1})$. Note the decrement of $\mathrm{PD}$ and $\mathrm{PD}+\mathrm{H}$ vs. $\mathrm{N}(\mathrm{P}<0.05)$.

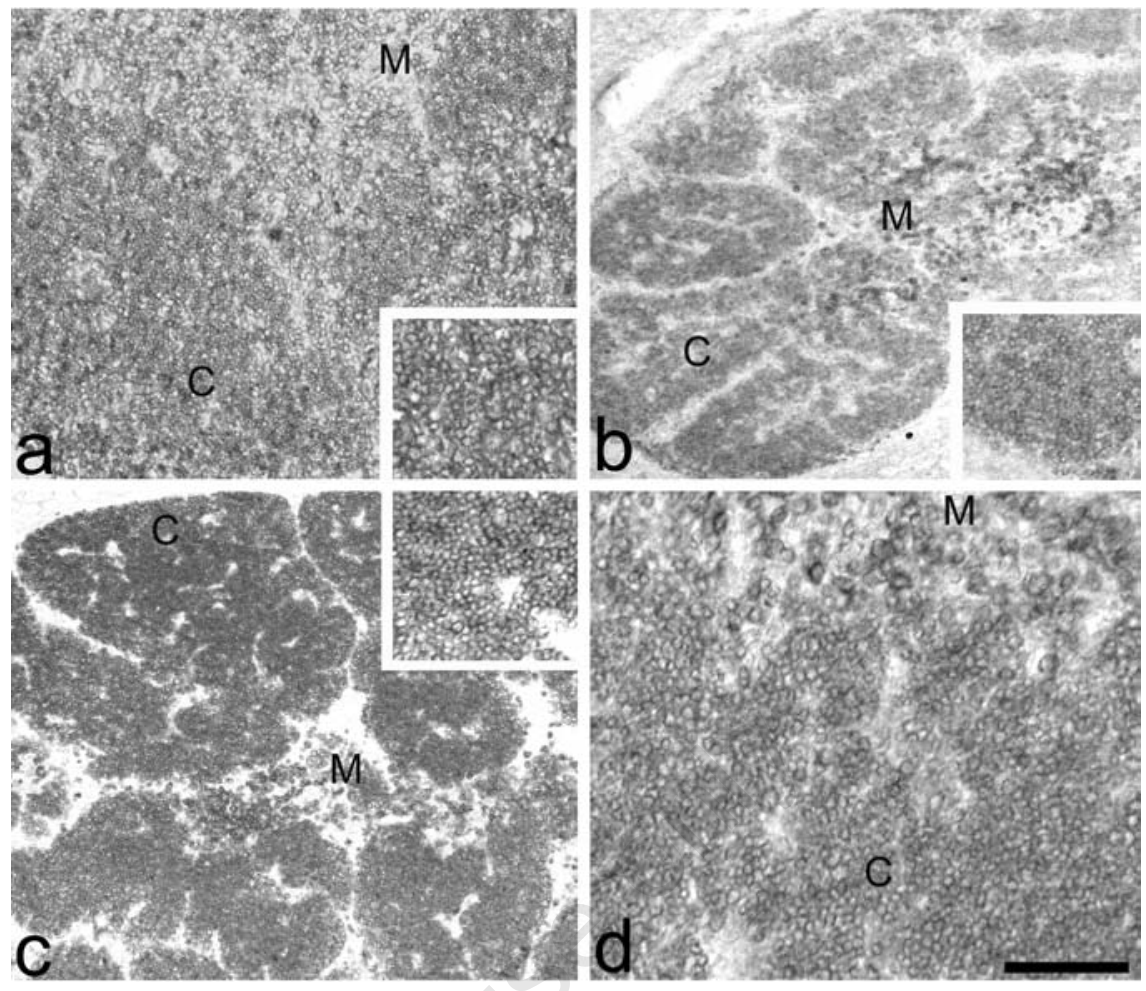

Figure 6. Anti-CD3 immune reaction. (a) Normal thymus. Strong membrane immune staining in the cortical $(C)$ and medullary $(M)$ thymocytes. Inset: magnification of positive cortical thymocytes. (b) PD thymus. Reduction of the number of cortical (C) and medullary (M) reactive thymocytes. Inset: magnification of positive cortical thymocytes. (c) $\mathrm{PD}+\mathrm{H}$ thymus Recovery of the total number of cortical $(\mathrm{C})$ and medullary $(\mathrm{M})$ reactive thymocytes. Inset: magnification of positive cortical thymocytes. (d) PD+Th thymus. Consistent recovery of the number of immune reactive thymocytes in the cortex and in the medulla. Scale bar: a: $28 \mu \mathrm{m}$; b,d: $40 \mu \mathrm{m}$; c: $50 \mu \mathrm{m}$.

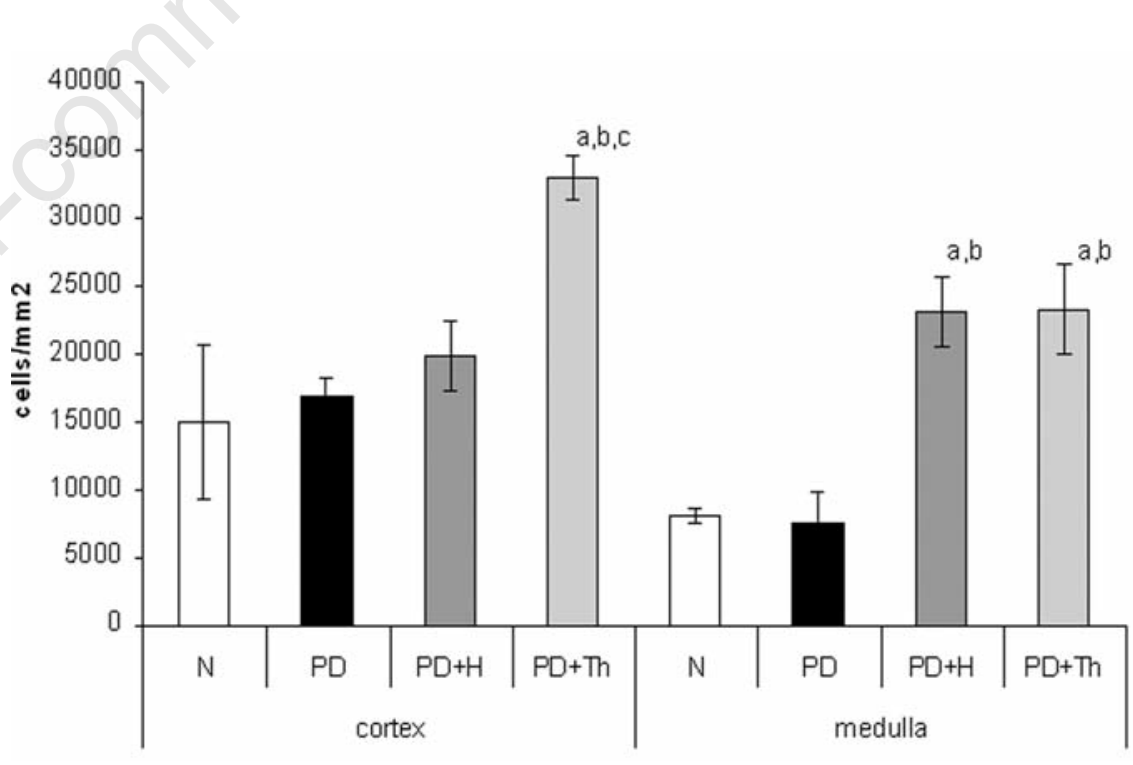

Figure 7. Anti-CD3- Density (number of cells $/ \mathrm{mm}^{2}$ ) of CD3+ thymocytes (detected by immune histochemistry) in thymic cortex and medulla of normal $(\mathrm{N})$, partially decerebrated $(P D)$, partially decerebrated + hypophyseal graft $(P D+H)$ and partially decerebrated + thymus graft $(P D+T h)$. Data refer to quantitative analysis on tissue section and are expressed as mean \pm SD. The two-tail Student $t$-test for unpaired data shows a significantly increase number of positive cells in cortex (a: $P D+T h$ vs. $N, P<0.001$; b: $P D+T h$ vs. $P D$, $\mathrm{P}<0.001$; c: $\mathrm{PD}+\mathrm{Th}$ vs. $\mathrm{PD}+\mathrm{H}, \mathrm{P}<0.001)$. In medulla, $\mathrm{PD}+\mathrm{H}$ and $\mathrm{PD}+\mathrm{Th}$ evidence a significant increment vs. $\mathrm{N}(\mathrm{a}, \mathrm{P}<0.001)$ and $\mathrm{PD}(\mathrm{b}, \mathrm{P}<0.001)$. 
image analysis. These results are similar to the ones found in previous researches ${ }^{55,76}$ in the thymus, in bursectomized embryos. These results are in some way difficult to explain. In fact, Kurki et al. ${ }^{77}$ found that unstimulated human peripheral blood T-lymphocytes were PCNA negative and their expression was evident only after stimulation. The PCNA immune reaction was thus indicated as a marker for Tlymphocytes committed to DNA synthesis and occuring later in G1 phase of the cell cycle; whereas Turka et al..$^{78}$ tested peripheral blood T lymphocytes and cell suspension of thymic tissue from children under 3 years of age. They found that PCNA protein higher level was present in immature double positive thymocytes, than both in single positive thymocytes and in peripheral blood T lymphocytes. The PCNA double positive thymocytes displayed low RNA content, characteristic of the resting cells in G0 phase. The authors ${ }^{78}$ indicated that the high levels of PCNA in these resting cells might mean a differential regulation during lymphoid development and contribute to the process of thymic selection and found that thymocytes, more or less expressed PCNA reaction.

Obviously we cannot deduce if the strong reaction in every cortical thymocyte of the normal thymus may represent PCNA content only in resting cells or in $\mathrm{S}$ phase cells, or in both.

On the contrary, in the thymocytes of the PD embryos the faint reaction may indicate that the thymocytes are in a different cell-division cycle, as indicated by Bravo and MacDonaldBravo $^{59}$ in an immune fluorescence study in 3T3 cells. The authors described the presence of two populations of PCNA/cyclin expressed in resting cells and during the $\mathrm{S}$ phase from $\mathrm{Gl}$ to G2, evident when formaldehyde fixation was used, as we did in our research. In the medulla, thymocytes of both normal and PD embryos do not express PCNA immune-reaction. This finding, in our opinion, reveals that thymocytes ceased to proliferate, or that the reaction is very weak and no detectable.

Hypophyseal or thymic grafts stress different aspects. In the case of the graft of hypophysis, the recovery of the localization of PCNA thymocytes are similarly distributed as in the normal thymus; however, the number of positive cells is dramatically inferior to the normal, as revealed by statistical analysis. On the contrary, very interesting data are observed in PD+Th (particularly in those with the graft without histological structure), where an enhancement of the number of PCNA positive thymocytes, throughout the cortex, is surprisingly higher than that found in normal thymus, confirmed also by statistical analysis.

Like PCNA, the expression of the CD3 marker also differs, to some extent, in normal and in the experimental thymuses. In all the thymocytes of normal embryos, throughout the cortical zone, and the medulla, CD3 was well expressed. This finding fits in with evidence that at the time when prothymocytes proliferate and differentiate in the thymus, the cellular expression of both the T cell receptor (TCR) and the non-polymorphic parts of the TCR complex, are referred to as CD3 antigens. ${ }^{67}$ The TCR, associated with the molecular complex CD3, is necessary for the membrane expression of the $\alpha \beta$ heterodimer and serves to transmit the signal generated at the cell surface to the interior and thereby to induce the appropriate effectual function. ${ }^{79}$ The kinetics of $\mathrm{T}$ cell differentiation and maturation in the thymus were studied in mammals and in human $^{66,67,80}$ and it was shown that the immune system of the chicken functions in a similar way to that of mammals and human. ${ }^{65,81}$

In our experiments, in the cortex of PD and $\mathrm{PD}+\mathrm{H}$, there is not a foreseeable decrease of CD3 expression, as shown also by statistical analysis. This finding could be explained by the fact that the hypophysis does not interfere in the expression of this marker on thymocytes. On the contrary, in the cortex of PD+Th there is a statistical significant increment of positive cells, underlining the difference between the poor role of the hypophysis and the greater contribution of the thymus. However, in the medulla, the graft of hypophysis or thymus, both provoked a strong statistical increment of positive cells vs. normal and PD. The detected increment of positive cells in cortex and in medulla of PD+Th, compared with control, may be due to thymic growth factors and probably also to thymocytes coming from the graft, permitting a better thymic differentiation. It is more difficult to explain why in the medulla of $\mathrm{PD}+\mathrm{H}$ the increment observed is statistical greater than that observed in PD and mostly in the control. We may suppose that the density per area of CD3 cells is greater because thymocytes do not differentiate further on. In our opinion, these data confirm that the lack of hypophysis causes the thymic morphological under-development and decreases the possibility of cortical thymocytes to proliferate and differentiate. The hypophyseal graft allows a partial recovery of the morphological but not of the functional aspect, while the thymic graft, mostly that without histological structure, may substantially influence the recovery of the thymic functions, due to thymic growth factors and probably also to an emigration of thymocytes.

\section{References}

1. Le Douarin NM, Dieterlen-Lievre F, Oliver PD. Ontogeny of primary lymphoid organs and lymphoid stem cells. Am J Anat 1984;
170:261-99.

2. Cooper MD, Chen CL, Bucy RP, Thompson CB. Avian T cell ontogeny. Adv Immunol 1991;50:87-117.

3. Glick B. The Bursa of Fabricius: the evolution of a discovery. Poultry Sci 1994;73: 979-83.

4. Aita M. Regulation of cellular immunology: general aspects of the function of the thymic microenvironment. In: Wegmann RJ and Wegmann MA eds. Recent Adv in Cell Mol Biol, vol 1. Peeters Press, Leuven, Belgium 1992, pp.1-10.

5. Boyd RL, Wilson TJ, Bean AG, Ward HA, Gershwin ME. Phenotipic characterization of chicken thymic stromal elements. Dev Immunol 1992;2:51-66.

6. Wilson TJ, Davidson NJ, Boyd RL, Gershin ME. Phenotypic analysis of the chicken thymic microenvironment during ontogenic development. Dev Immunol 1992;2: 19-27.

7. Kendall MD. Avian thymus gland: a Review. Dev Comp Immunol 1980;4:191210.

8. Romano N, Casini P, Abelli L, Mastrolia L, Aita M. Influence of partial decerebration and hypophyseal allograft on differentiation of thymic epithelial cells in chick embryo and ultrastructural study. Anat Embryol 1996;193:593-600.

9. Chan AS. Ultrastructural observations on cytodifferentiation of thymic cystic cells of chick embryo. Thymus 1991;17:115-22.

10. Chan AS. Ultrastructure of epithelial cells of the chick embryo thymus. Acta Anatomica 1994;150:96-103.

11. Aita M, Mazzone AM, Gabrielli F, Evangelista A, Brenna S. Identification of cells secreting a thymostimulin-like substance and examination of some histoenzymatic pathways in aging avian primary lymphatic organs: I. Thymus. Eur J Histochem 1995;39:289-300.

12. Crivellato E, Nico B, Ribatti D. Endocrinelike cells in the Chick Embryo Thymus express ultra structural features of piecemeal degranulation. Anat Rec A Discov Mol Cell Evol Biol 2005;282:106-9.

13. Comsa J, Leonhardt $\mathrm{H}$, Wekerle $\mathrm{H}$. Hormonal coordination of the immune response. Rev Physiol Biochem Pharmacol 1982;92:115-91.

14. Blalock JE. A molecular basis for bidirectional communication between the immune and neuroendocrine systems. Physiol Rev 1989;69:1-32.

15. Marchetti B, Morale MC, Pelletier G. The thymus gland as a major target for the central nervous system and the neuroendocrine system: neuroendocrine modulation of thymic $\beta 2$-adrenergic receptor distribution as revealed by in vitro autoradi- 
ography. Mol Cell Neurosci 1990;1:10-9.

16. Marchetti B, Morale MC, Pelletier G. Sympathetic nervous system control of rat thymus gland maturation: autoradiographic localization of the $\beta 2$-adrenergic receptors in the thymus and presence of sexual dimorphis during ontogeny. Progress Neuroimmunol 1990;3:103-15.

17. Besedovsky HO, Del Rey A. Immuneneuro-endocrine interactions: facts and hypotheses. Endocr Rev 1996;17:64-102.

18. Savino W, Dardenne M. Neuroendocrine control of thymus physiology. Endocr Rev 2000;21:412-43.

19. Marchetti B. Involvement of the thymus in reproduction. Prog. Neuroendocrineimmunol 1989;2:64-9.

20. Marchetti B, Guarcello V, Morale MC, Bartolini G, Farinella Z, Cordaro S, et al. Luteinizing hormone-releasing-binding sites in the rat thymus: characteristics and biological function. Endocrinology 1989; 125:1025-36.

21. Klecka AJ, Genaro AM, Gorelik G, Barreiro Arcos ML, Silberman DM, Schuman M, et al. Integrative study of hypothalamus-pituitary-thyroid-immune system interaction: thyroid hormone-mediated modulation of lymphocyte activity through the protein kinase C signaling pathway. J Endocrinol 2006;189:45-55.

22. Lutton B, Callard I. Evolution of reproductive-immune interactions. Integrative Comp Biol 2006;46:1060-71.

23. Vacchio MS, Papadopoulus V, Ashwell JD. Steroid production in the thymus: implications for thymocyte selection. J exp Med 1996;179:1835-46.

24. Ottaviani E, Franchini A, Franceschi C. Presence of immunoreactive corticotropin-releasing hormone and cortisol molecole in invertebrate haematocytes and lower and higher vertebrate thymus. Histochem J 1998;30:61-7.

25. Lechner 0, Dietrich H, Wiegers GJ, Vacchio M, Wick G. Glucocorticoid production in the chicken bursa and thymus. Int Immunol 2001;13:769-76.

26. Gomez-Sanches CE. Glucocorticoid production and regulation in thymus of mice and birds. Endocrinology 2009;150:3977-9.

27. Hull KL, Thiagarajah A, Harvey S. Cellular localization of growth hormone receptors/binding proteins in immune tissues. Cell Tissue Res 1996;286:69-80.

28. Ottaviani E, Franchini A, Franceschi C. Evolution of neuroendocrine thymus: studies on POMC-derived peptides, cytokines and apoptosis in lower and higher vertebrates. J Neuroimmunol 1997;72:67-74.

29. Franchini A, Ottaviani E. Immunoreactive POMC-derived peptides and cytokines in the chicken thymus and bursa of Fabricius microenvironments: age-related changes. J Neuroendocrinol 1999;11:685-92.

30. De Luca A, Squillacioti C, Pero ME, Paino S, Langella E, Mirabella. Urocortin-like immuno reactivity in the primary lymphoid organs of the duck (Anas platyrhynchos). Eur J Histochem 2009;53:167-76.

31. Atoji Y, Yamamoto Y, Suzuki Y. Neurotensin-containing endocrine cells and neurotensin receptor mRNA-expressing epithelial cells in the chicken thymus. Arch Histol Cytol 1996;59:197-203.

32. Atoji Y, Yamamoto Y, Komatsou T, Suzuki Y. Localization of neuropeptides in endocrine cells of the chicken thymus. $\mathrm{J}$ Vet Med Sci 1997;59:601-3.

33. Goya RG, Brown OA, Bolognani F. The thymus-pituitary axis and its changes during aging. Neuroimmunomodulation 1999;6: 137-142.

34. Greeps R0 (ed) Recent progress in hormone research., vol. 37, 1981. Acad Press London, UK.

35. Fabien N, Auger C, Monier J-C. Immuno localization of thymosin $\alpha 1$, thymopoietin and thymulin in mouse thymic epithelial cells of different stages of culture: a light and electron microscopic study. Immunology 1988;63:721-7.

36. Monier JC, Auger C, Fabien N. Les hormones thymiques. Arch Int Physiol Biochim 1988;96:A2-26.

37. Brewer JM, Wunderlich JK, Ragland WL. The amino acid sequence of avian thymic hormone, a parvalbumin. Biochimie 1990; 72:653-60.

38. Kiràly E, Celio MR. Parvalbumin and calretinin in the avian thymus. Anat Embryol (Berl) 1993;188:339-44.

39. Falchetti R, Bergesi G, Eshkol A, Cafiero C, Adorini L, Caprino L. Pharmacological and Biological properties of a calf thymus extract (TP1). Drugs Exp Clin Res 1977;3: 39-47.

40. Aita M, Cocchia D, Minella AB, Amantea A. Identification of thymostimulin secreting cells in calf thymus by immunoperoxidase method. Histochemistry 1984;80:207-11.

41. Aita M, Minella AB, Palermo D. Localization of thymostimulin in mouse and rat thymuses. Basic Appl Histochem 1986;30:53-9.

42. Aita M, Minella AB, Palermo D, Gabrielli F, Franzé A. Localization of thymostimulin in mammalian thymuses: comparative evaluation. Cell Mol Biol 1989;35:137-45.

43. Aita M, Amantea A. Distribution of antikeratins and anti-thymostimulin antibodies in normal and in Down's syndrome human thymuses. Thymus 1991;17:155-65.

44. Aita M, Brenna S, Mazzone AM. Thymo stimulin-like immunoreactions in avian thymus and Bursa of Fabricius. Basic Appl
Histochem 1989;3:suppl 9.

45. Aita M, Mazzone AM, Gabrielli F, Evangelista A, Brenna S. Identification of cells secreting a thymostimulin-like substance and examination of some hystoenzimatic pathways in aging avian primary lymphatic organs: I. Thymus. Eur J Histochem 1995;39:289-300.

46. Aita M, Romano N. Effects of partial decerebration and hypophyseal allograft in the thymus of chicken embryos: thymostimulin localization and enzymatic activities. Eur J Histochem 2006;50:69-78.

47. Fugo NW. Effects of hypophysectomy in the chick embryo. J exp Zool 1940;85:271-91.

48. Betz TW. The effects of embryonic pars distalis grafts on the development of hypophysectomized chick embryos. Gen comp Endocrinol 1967;9:172-186.

49. Jankovic BD, Isakovic $\mathrm{K}$, Micic $\mathrm{M}$, Knezevic Z. The embryonic-lympho-neuroendocrine relationship. Clin Immunol Immunopathol 1981;18:108-20.

50. Mastrolia L, Aita M, Romano N, Gallarello F, Jamele M, Manelli H. Histological study of the primary lymphatic organs in partially decerebrated chicken embryos. Acta Embryol Morphol Exper 1986;7:112.

51. Herradòn PG, Razquin B, Zapata Ag. Effects of early partial decapitation on the ontogenic development of chicken lymphoid organs. I. Thymus. Am J Anat 1991; 191:57-66.

52. Moreno J, Vicente A, Varras A, Zapata A G. T-cell development in early partially decapited chicken embryos. Dev Immunol 1995;4:211-26.

53. Mastrolia L, Aita M, Romano N, Evangelista A, Manelli F, Manelli H. Effects of hypophyseal grafts on thymus and bursa of Fabricius in partially decerebrated chick embryos Acta Embryol Morphol Exper 1987;8:419-26.

54. Aita M, Carafelli E, Zamponi F, Alfei L. Distribution of calcium-binding proteins and CD3, PCNA/cyclin in thymuses of partially decerebrated and thymic-grafted chicken embryos. 1999, Congress of Società Italiana di Fisiologia, Rome, Italy, p 195 (abstr).

55. Aita M, Carafelli E, Alfei L, Caronti B. Thymic development in surgically bursectomized embryonic chicken: expression of PCNA, CD3, CD4 and CD8 markers. Eur J Histochem 2007;51:241-50.

56. Bravo R. Coordinated synthesis of the nuclear protein cyclin and DNA in serumstimulated quiescent 3T3 cells. FEBS Lett 1984;169: 185-8.

57. Bravo R. Synthesis of the nuclear protein cyclin (PCNA) and its relationship with DNA replication. Exp Cell Res 1986;163: 287-93. 
58. Bravo R, Graf T. Synthesis of the nuclear protein cyclin does not correlate directly with transformation in quail embryo fibroblasts. Exp Cell Res 1985;156:450-4.

59. Bravo R, Macdonald-Bravo H. Existence of two populations of cyclin/proliferative cell nuclear antigen during the cell cycle: association with DNA replication sites. J Cell Biol 1987;105:1549-54.

60. Bravo R, Fey SJ, Bellatin J, Larsen PM, Arevalo J, Celis JE. Identification of a nuclear and of a cytoplasmic polipeptide whose relative proportions are sensitive to changes in the rate of cell proliferation. Exp Cell Res 1981;136:311-9.

61. Mathews MB, Bernstein RM, Franza BR jr, Garrels JI. Identity of the proliferating cell nuclear antigen and cyclin. Nature 1984; 309:374-6.

62. Crute JJ, Wahl AF, Bambara RA. Purification and characterization of two new high molecular weight forms of DNA polymerase $\delta$. Biochemistry 1986;25:26-36.

63. Tan CK, Castillo C, So AG, Downey KM. An auxiliary protein for DNA polymerasedelta from fetal calf thymus. J Biol Chem 1986;261:12310-16.

64. Bravo R, Frank R, Blundell PA, MacdonaldBravo H. Cyclin/PCNA is the auxiliary protein of DNA polymerase-delta. Nature 1987;326:515-7.

65. Chan MM, Chen CH, Ager LL, Cooper MD. Identification of the avian homologues of mammalian CD4 and CD8 antigens. J
Immunol 1988;140:2133-8.

66. Strominger JL. Developmental Biology of T cell receptors. Science 1989;244:943-50.

67. Janossy G, Campana D, Akbar A. Kinetics of T lymphocyte development. Curr Top Pathol 1989;79:59-99.

68. Dunon D, Allioli N, Vainio O, Ody C, Imhof BA. Renewal of thymocyte progenitors and emigration of thymocytes during avian development. Dev Comp Immunol 1998;22: 279- 87.

69. Dunon D, Imhof BA. T cell migration during ontogeny and T cell repertoire generation. Curr Top Microbiol Immunol 1996; 212:79-93.

70. Dunon D, Imhof BA. The role of cell traffic in the emergence of the T lymphoid system. Semin Immunol 2000;12:429-33.

71. Hamilton H. Lillie's development of the chick: an introduction to embryology. Halt H (ed.) NY, USA, 1952, pp. 78-91.

72. Waseem NH, Lane DP. Monoclonal antibody analysis of the proliferating cell nuclear antigen (PCNA). Structural conservation and the detection of a nucleolar form. J Cell Sci 1990;196:121-9.

73. Alunni A, Pierucci F, Aita M, Margotta V, De Vita R, Alfei L. Proliferative activity and motoneurone recruitment persist at the spinal cord central canal during larval and some postlarval stages in the rainbow trout (Oncorhynchus mykiss). Eur J Histochem 2001;45:191-202.

74. Yu CC-W, Woods AL, Levison DA. The assessment of cellular proliferation by Immunohistochemistry: a review of currently available methods and their applications. Histochem J 1991;24:121-31.

75. Aita M, Caccia E, Romano N. Thymus development is influenced by hypophyseal and thymic allograft after hypophysectomy: expression of PCNA and CD3 markers. Invertebr Surv J 2008;5:38.

76. Aita M, Romano N. Thymic morpho-functional changes after hypophysectomy and bursectomy in chicken embryos. Invertebr Surv J 2007;4:29-30.

77. Kurki P, Lotz M, Ogata K, Tan EM. Proliferating cell nuclear antigen (PCNA)/ cyclin in activated human $\mathrm{T}$ lymphocytes. $\mathrm{J}$ Immunol 1987;138:4114-20.

78. Turka LA, Gratiot-Deans J, Keim D, Bandukwala R, Green J, Strahler J, et al. Elevated proliferating cell nuclear antigen levels in immature thymocytes. J Immunol 1993;150:2746-52.

79. Blackman M, Kappler J, Marrack P. The role of the $\mathrm{T}$ cell receptor in positive and negative selection of developing T cells. Science 1990;248:1335-41.

80. Campana D, Janossy G, Coustan-Smith E, Amlot PL, Tian WT, Ip S, et al. The expression of T cell receptor-associated proteins during $\mathrm{T}$ cell ontogeny in man. $\mathrm{J}$ Immunol 1989;142:57-66.

81. Vainio 0, Imhof BA. The immunology and developmental biology of the chicken. Immunol Today 1995;16:365-70. 